\title{
VESITORNISTA TAITEEN TORNIKSI
}

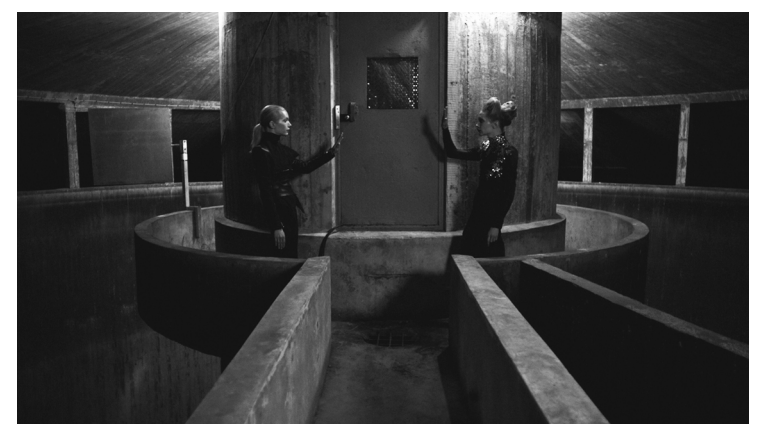

STILL-KUVA HENNA-RIIKKA HALOSEN LAUTTASAAREN VESITORNISSA KUVATUSTA THE VESSEL -ELOKUVASTA 2013.

Sienen muotoinen Lauttasaaren vesitorni valmistui 1958 uuden betonirakentamisen monumentiksi. Tornin suunnittelusta vastasivat arkkitehti Osmo Leppämäki ja insinööri Paavo Simula. Se oli ensimmäinen suuri kartionmallinen vesitorni, tekninen innovaatio. Tornista tuli pian Lauttasaaren symboli.

Teknologian muutokset synnyttävät uutta arkkitehtuuria ja samalla jättävät jälkeensä rakennuksia vailla alkuperäistä käyttötarkoitusta. Lauttasaaren vesitorni on ollut tyhjillään vuodesta1996. Asukkaat ovat halunneet siitä näkötornin, mutta virkamiehet ovat haranneet vastaan ja poliitikot ovat olleet laiskoja.

Lauttasaaren vesitornin ulkoinen muoto on innostanut taiteilijoita toteuttamaan erilaisia valotaiteellisia projekteja, ja myös sisätilat ovat toimineet taide-esitysten näyttämönä. Osmo Harkimon 1960-luvun alussa ohjaamassa kokeellisessa elokuvassa Opus $\mathrm{H}_{2} \mathrm{O}$, Rapsodia vedelle Heikki Värtsi ryhmineen tanssi vesitornin sisällä kiertävällä parvekkeella tulevaisuuden tulkinnan Jaakko Salon musiikkiin.

Myös nykytaiteilijat yhdistävät Lauttasaaren vesitornin tieteisvisioihin.”Lyhytelokuvani kuvaa androgyynin hahmon matkaa ja muodonmuutosta vesitornissa scifi-fantasian keinoin", HennaRiikka Halonen kertoo The Vessel -elokuvastaan, jota hän valmistelee vuoden 2014 Sidneyn biennaalia varten. Taiteilijan mielestä aika saa rakennuksessa uuden merkityksen, ja elokuva tuo esiin arkkitehtuurin mielentilana.

Caspar Stracken järjestämässä Nordic Sound Art -festivaalin työpajassa tutkittiin erityisesti vesitornin säiliön kaikua. Elina Lifländerin työryhmä puolestaan keskittyi vesitornin massiivisessa säiliötilassa syntyviin reaktioihin ja assosiaatioketjuihin."Meitä kiehtoi ajatus tornin epävarmasta tulevaisuudesta. ... innostuimme paikan akustiikasta, loputtomasta sakraalista kaiusta, rytmistä ja surrealistisesta säiliömaisemasta, jossa kaikki pinnat olivat kaarevia tai kaltevia. ... Tornissa viettämämme aika oli verrattavissa yhteiseen matkaan kaukomailla tai avaruudessa, jossa yöt ja päivät, ajan ja paikan taju hämärtyivät.”

Helsingin kaupunginhallitus on päättänyt purkaa Lauttasaaren vesitornin asukkaiden vastarinnasta huolimatta. Monet kaupunkilaiset haluavat tornista maamerkin ja taidetapahtumien näyttämön.

Allekirjoittamalla Pro Lauttasaaren vesitorni -adressin - http://www.adressit.com/pro_lauttasaaren_vesitorni - tuet mahdollisuutta kehittää tornia maamerkkinä ja vaihtoehtoisena taidetilana. 